\title{
Progressive changes in serum cortisol, insulin and growth hormone concentrations and their relationship to the distorted amino acid pattern during the development of kwashiorkor
}

\author{
By P. G. LUNN, R. G. WHITEHEAD, R. W. HAY ANd B. A. BAKER \\ Medical Research Council Child Nutrition Unit, \\ PO Box 6717, Kampala, Uganda \\ (Received 13 fune $1972-$ Accepted $1_{4}$ October 1972)
}

\begin{abstract}
I. During the initial stages of the development of hypoalbuminaemia, with concentrations between 25 and $30 \mathrm{~g} / 1$, fasting serum cortisol and growth hormone values remained normal. Corresponding fasting serum insulin concentrations were, however, significantly above normal. During the same period, called phase $\mathbf{B}$, valine concentrations were moderately low but alanine concentrations were raised.

2. In more severe hypoalbuminaemia, culminating in kwashiorkor, a marked switch in hormonal balance occurred. Insulin concentrations fell to subnormal levels whereas cortisol became raised. Eventually growth hormone concentrations also increased rapidly to values similar to those found in acromegaly. By this time, phase $\mathrm{C}$, alanine concentrations as well as those of valine were falling to very low levels.

3. The possible causes of these changes in hormonal balance, their role in the development of the distorted fasting serum amino acid pattern and their consequent effect on serum albumin synthesis and the appearance of clinical kwashiorkor are discussed.

4. Information is also presented on the differences between these components in kwashiorkor and marasmus. Attempts have been made to rationalize apparent inconsistencies in the literature.
\end{abstract}

There is growing interest in the changes which occur in the function of various endocrine organs during the pathogenesis of protein-energy malnutrition. However, most reports so far have been restricted to the measurement of a single hormone rather than to changes among a series of metabolically interrelated hormones. Moreover, they have only dealt with the acute situation, although it is becoming increasingly clear that the general metabolic pattern seen in cases on admission to hospital can be quite different from that which has existed during most of the earlier stages of chronic malnutrition, before the acute episode.

In this investigation we have studied simultancously three hormones which are important in the regulation of protein and amino acid metabolism, insulin, cortisol, and growth hormone (GH). These have been measured both in patients in hospital and, serially, in children attending an out-patient clinic in an area of Uganda where kwashiorkor is endemic. The concentrations of certain plasma amino acids have also been measured and an attempt has been made to correlate the changes observed with those found in the hormone levels. 
METHODS

\section{Subjects}

Two types of subjects were investigated. The first group were selected from forty children from a rural village clinic who were being studied serially both medically and biochemically during the first 3 years of life. This investigation into the pathogenesis of protein-energy malnutrition in Uganda has been described briefly elsewhere (Frood, Whitehead \& Coward, I97I). The second series of children consisted of seventy-two cases of oedematous malnutrition (kwashiorkor) and nine of marasmus. Treatment in hospital was according to Staff ( 1968 ). The mean age of the kwashiorkor patients was 20.6 months and of the marasmics, 16.7 months.

The children in hospital were bled after an overnight fast. This precaution was not possible for the clinic children, but the traditional habit in the area is to eat little or no breakfast and experience has shown that samples collected during the morning are essentially fasting. All samples were collected between 08.00 and I2.00 hours. Serum was stored at $-20^{\circ}$ before analysis.

\section{Analytical techniques}

Cortisol. Serum cortisol was measured by an adaptation of the protein-binding radioassay described by Murphey ( 1967 ), which allowed the steroid to be assayed in $50 \mu 1$ serum. Normal rabbit plasma was used as the source of transcortin for the method. Although this assay is more specific for cortisol than the fluorimetric methods, other corticosteroids do contribute to the final value obtained; however, in man, cortisol is the main component so the actual error is very small.

Insulin. Serum insulin was measured by the radioimmunoassay method ' $C$ ' of Hales \& Randle (I963) with equipment supplied in kit form by the Radiochemical Centre (Amersham). An insulin standard prepared by Wellcome Reagents Ltd, Beckenham, and supplied with the kits was used as the reference.

$G H$. Serum GH was measured by the double antibody radioimmunoassay method described by Molinatti, Massara, Strumia, Pennisi, Scasellati \& Vancheri (1969). This procedure is essentially the same as the insulin assay of Hales \& Randle (1963) and materials for the assay were obtained from the Commissariat à L'Energie Atomique (France). The GH standard prepared at the Clinical Physiology Laboratory of the National Research Council, Pisa, Italy, was used as the reference. This experimental technique produced excellent reproducibility between duplicate and triplicate assays.

Albumin and amino acids. Serum albumin was measured by an automated microtechnique (Coward, Sawyer \& Whitehead, I97I). Serum valine and alanine concentrations were determined on a Technicon TSM-I Amino Acid Analyzer using the shortened programme of Grimble \& Whitehead (I97 $a$ ). Albumin and amino acid analyses were performed routinely and thus more results are available for these serum components than for the hormones.

Glucose. Blood glucose was also measured using a modified AutoAnalyzer system (Technicon method sheet N-9a). 


\section{Infections}

During the course of the interpretation of the cortisol results it became necessary to try to classify the severity of infection in those children who had been admitted to the ward. 'This was done retrospectively from the ward notes using the following criteria.

No infection. Complete absence of clinical, microbiological, and parasitological signs.

Mild infection. Uncomplicated upper respiratory tract infections, skin sepses or worm infestations, all provided that the temperature was not above $38.5^{\circ}$.

Moderate infection. Any of the above if complicated, measles, lower respiratory tract infections, clinically overt malaria with parasitaemia, and other infections accompanied by pyrexia.

Severe infection. Children were placed in this category only when there were positive comments in the notes showing that the child had been very sick. In fact, four of the five children so classified eventually died; two with a septicaemia, one with enteritis and one with a lower respiratory tract infection. The child who survived had also had a severe enteritis.

\section{RISULTS}

\section{Cortisol}

Fig. I shows the relative changes in the concentrations of cortisol, insulin and $\mathrm{GH}$ in serial serum samples from clinic children and from cases of kwashiorkor on admission to the ward, analysed cross-sectionally by grouping the results according to albumin concentration.

During the initial phases of malnutrition, while serum albumin concentration was falling to $30 \mathrm{~g} / \mathrm{l}$, the mean cortisol values were not different from those of normal children, 90-I Iо $\mu \mathrm{g} / \mathrm{l}$; Ely, Kelly \& Raile (1953) quoted $100 \pm 16 \cdot 7 \mu \mathrm{g} / \mathrm{l}$ for healthy children in this age group. It was only when albumin values became less than $3 \circ \mathrm{g} / \mathrm{l}$ that serum cortisol concentrations became progressively raised.

Fig. 2a, $b$ show similar changes in serum cortisol and albumin concentrations in two individual clinic children who were studied longitudinally. In both examples, the hypoalbuminaemic episodes coincided with raised cortisol values. Since previous work from this unit had already shown that periods of hypoalbuminaemia were closely correlated with the pattern of infection (Frood et al. 197 I), it was not surprising that a similar association was found with raised cortisol concentrations. For example, the drop in albumin in Fig. $2 a$ occurred concurrently with successive attacks of bronchitis, pneumonia, malaria, infective diarrhoea, and malaria again; for the child in Fig. $2 b$ the relevant events were pneumonia, measles, malaria, and bronchitis.

The probable importance of infection in the interpretation of cortisol values was further emphasized by the results from the children who had been admitted to hospital with severe kwashiorkor; serum cortisol concentration was significantly related to the severity of infection (Fig. 3). Although mean admission values were higher in the noninfected cases compared with children on discharge, the greatest concentrations were found in the children whose malnutrition was complicated with the most severe infection. 


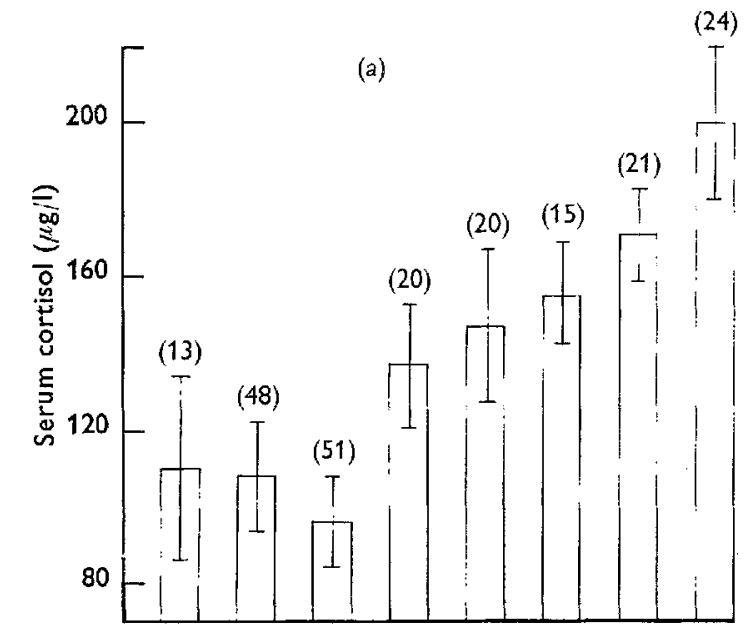

(24)
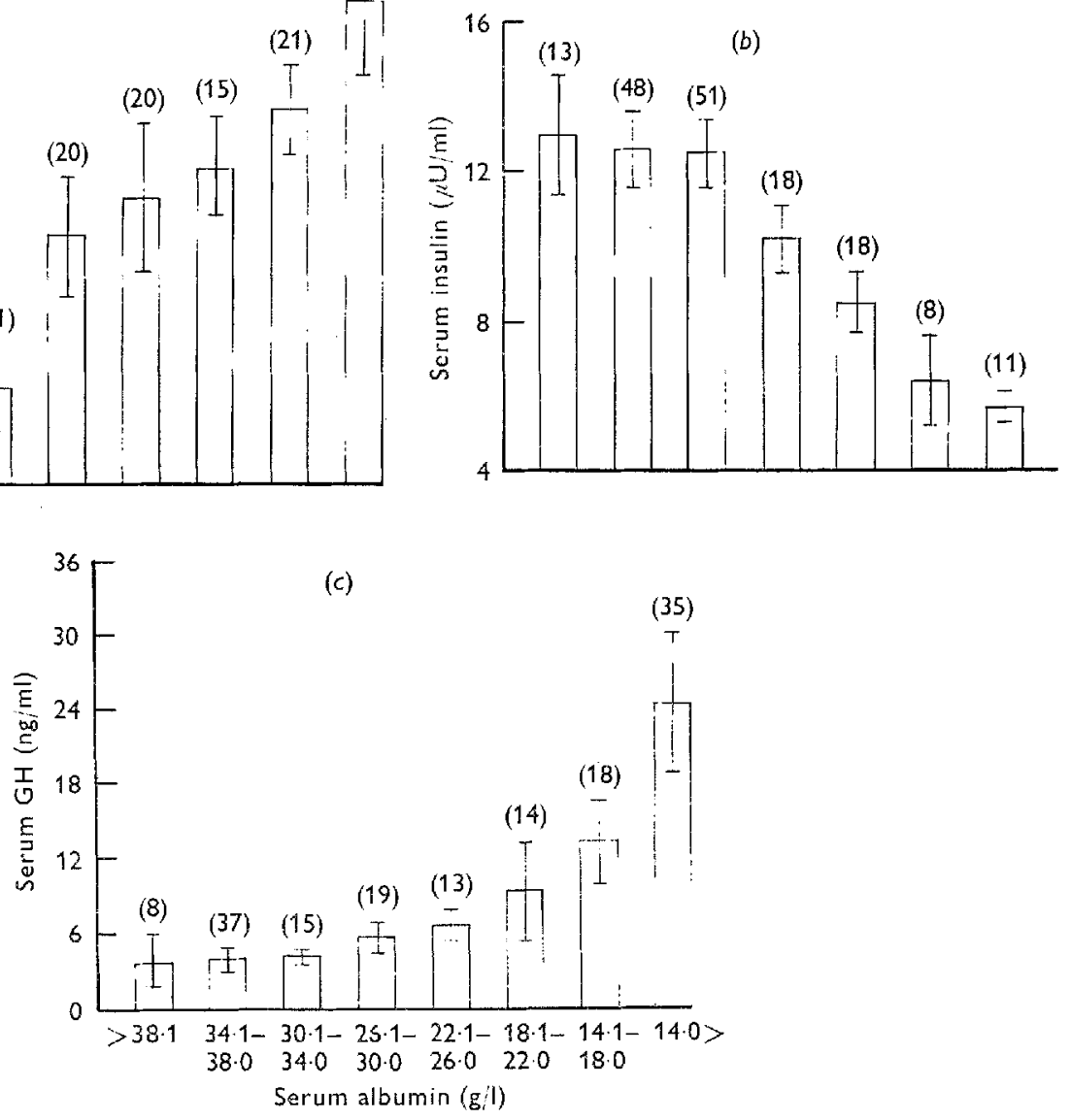

Fig. $x a, b, c$. Relationship between serum albumin and $(a)$ cortisol, $(b)$ insulin and $(c)$ growth hormone (GII) concentrations in children living in a kwashiorkor endemic area, and in others with the frank clinical condition, grouped according to scrum albumin concentration. Values are the means with their standard errors; figures in patentheses indicate the number of samples analysed.

(a) Mean serum cortisol values in the albumin group $30^{\circ} \mathrm{I}-34.0 \mathrm{~g} / 1$ are significantly different from the 22-26 g/l group, $P<0.05$ and the $\mathrm{I}+4 \mathrm{I} 8 \mathrm{~g} / \mathrm{l}$ group, $P<0.0 \mathrm{I}$, by the $t$ test.

(b) Mean serum insulin concentration in the $22 \cdot \mathrm{I}-26 \cdot 0 \mathrm{~g} / 1$ albumin group is significantly lower than that for the $30^{\circ} 1-34^{\circ} \circ \mathrm{g} / 1$ albumin range, $P<0 \times 01$. Three high serum insulin values from atypical children have been omitted from the kwashiorkor cases, for details see p. 405 .

(c) Mean serum GII concentration for the $14 \cdot 1 \cdots 18 \cdot 0 \mathrm{~g} / 1$ range of albumin values was significantly higher than the means for all albumin ranges above $30 \mathrm{~g} / 1, P<0.00 \mathrm{I}$.

As one of the actions of cortisol is to facilitate body wasting, which is a prime feature in the majority of malnourished children, it was considered that there might also be a relationship between serum cortisol concentration and body-weight deficit. In Fig. 4 admission serum cortisol concentrations have been grouped according to percentage expected weight for age. 'This was calculated on the basis of the lowest weight recorded 


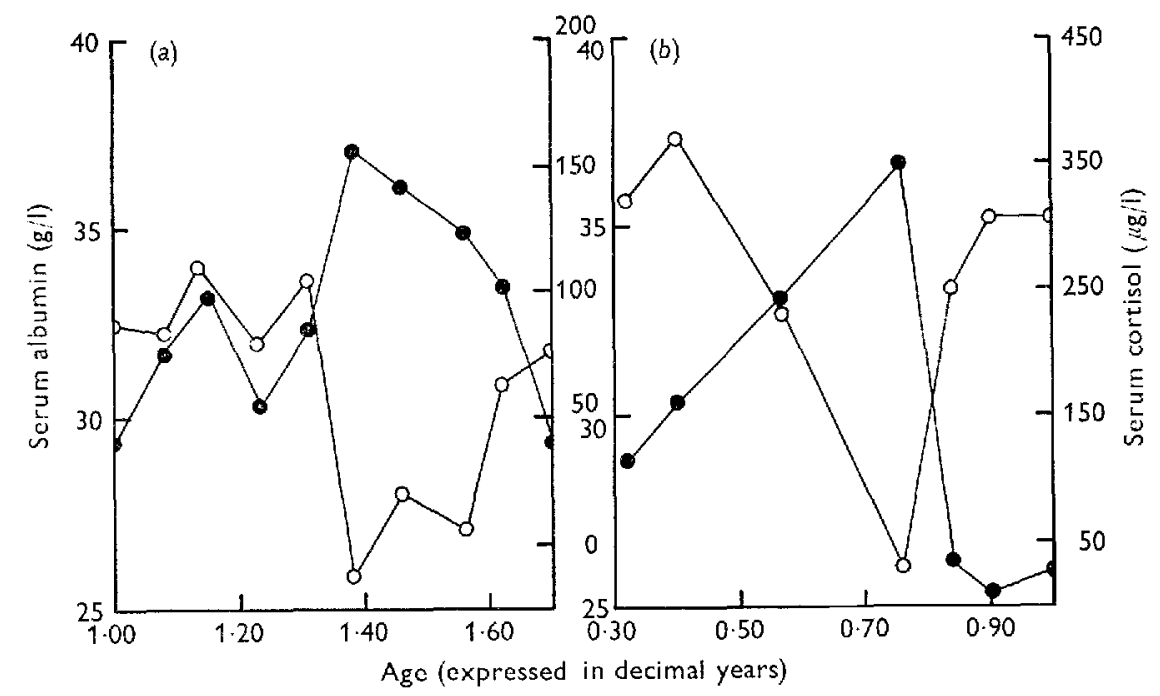

Fig. $2 a, b$. Relative changes in serum albumin (C) and cortisol concentration in two children living in a kwashiorkor endemic area.

following the loss of ocdema, generally about $7 \mathrm{~d}$ after admission, using the Boston weight standards (Stuart \& Stevenson, 1954). Values for marasmic children have also been included. In the kwashiorkor cases who were 90 roo \% of expected weight, and in whom presumably there had been very little body wasting, normal cortisol concentrations were found. However, as the body-weight deficit became more marked, mean cortisol values rose. In cases of marasmic kwashiorkor, that is, oedematous malnutrition with a body-weight of less than $60 \%$ of the expected value (Wellcome 'Trust Working Party, I970), the cortisol concentrations were very high, and not significantly different from the marasmic values. When weight deficit was compared with serum cortisol concentration using linear regression analysis, a highly significant correlation was obtained $(r=0.42, P<0.001)$.

One of the other stimuli for cortisol production is a low blood glucose concentration. However, when fasting blood glucose was measured in fifteen patients on admission, no values below $500 \mathrm{mg} / 1$ were found and there was no significant relation with serum cortisol concentration.

\section{Insulin}

Serum insulin concentrations among the rural clinic children and in the cases of kwashiorkor on admission and at discharge from the ward are summarized in Table $x$. 'The mean concentration on admission was much lower than that found in Uganda by ILadden (1967), 6.27 $\mu \mathrm{U} / \mathrm{ml}$ as opposed to $20 \mu \mathrm{U} / \mathrm{ml}$. Surprisingly, the latter author concluded that insulin concentrations were not reduced in kwashiorkor. 'The present values, in fact, were more like those reported by other workers (Baig \& Edozien, 1965; James \& Coore, I970; Milner, 1971). Mean insulin concentrations rose significantly on treatment, nevertheless concentrations on discharge were still lower than the average for the clinic children. 


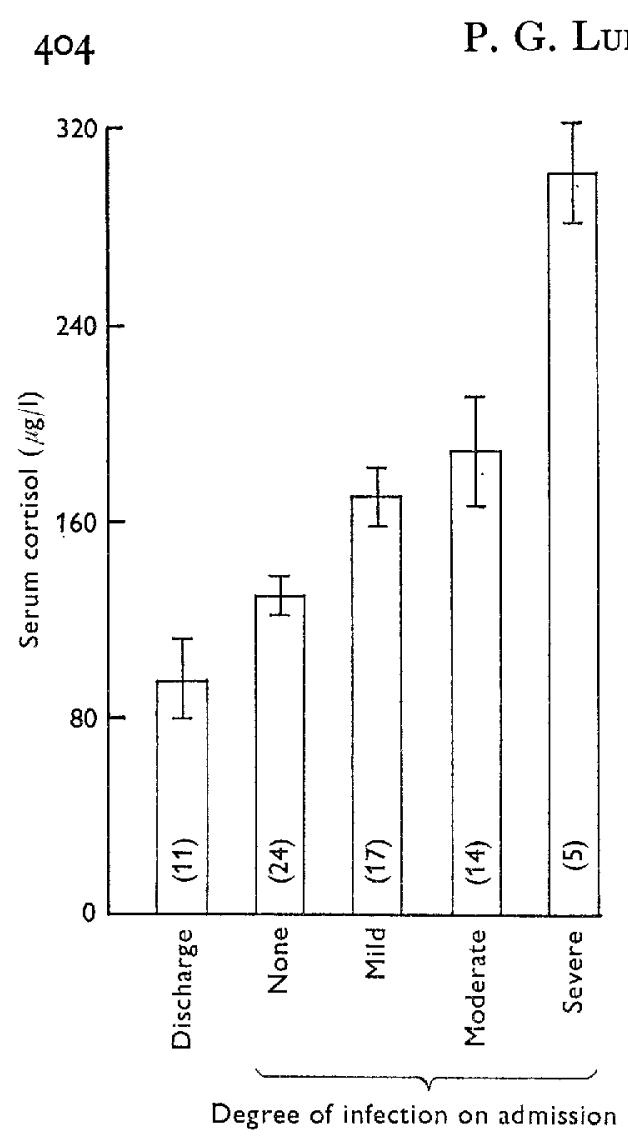

Fig. 3

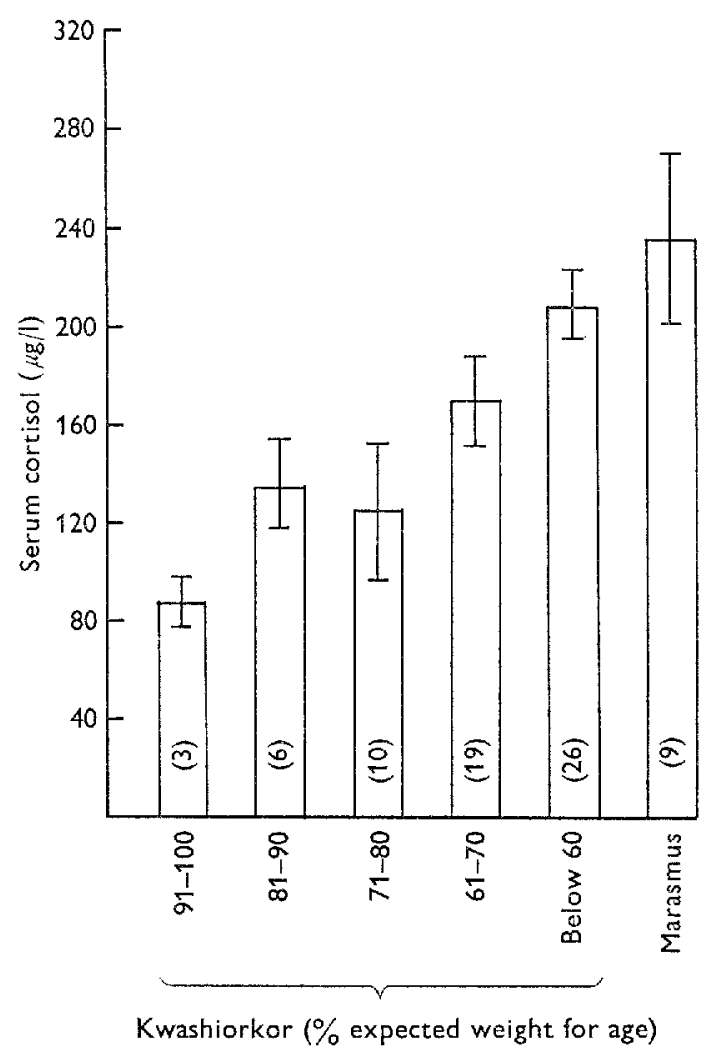

Fig. 4

Fig. 3. Relationship between serum cortisol concentrations and the severity of infection in children in hospital with untreated kwashiorkor, for details see p. 40r. The figures in parentheses indicate the number of cases. Values are means with their standard errots, those in children on discharge are significantly different from those for untreated children without infection, $P<0.02$; the values for uninfected cases are different from those for children with mild infections, $P<0.02$, and for severely infected children, $P<0.00$ I.

Fig. 4. Variation in serum cortisol concentration with weight deficit $(\%$ for age, see p. 403 for standard) in children admitted to the ward with kwashiorkor and marasmus. Figures in parentheses are the number of cases. Cortisol values in the groups greater than $80 \%$ significantly lower than those in the group less than $60 \%, P<0.005$; between kwashiorkor cases $<60 \%$ and the marasmics, not significant.

\section{Table ı. Fasting serum insulin concentrations in protein-energy malnutrition}

\begin{tabular}{|c|c|c|c|}
\hline \multirow[b]{2}{*}{ Subjects } & \multirow[b]{2}{*}{ No. of samples } & \multicolumn{2}{|c|}{$\begin{array}{l}\text { Insulin } \\
(\mu \mathrm{U} / \mathrm{ml})\end{array}$} \\
\hline & & Mean & $\mathrm{SE}$ \\
\hline $\begin{array}{l}\text { Rural clinic children } \\
\text { Kwashiorkor children: }\end{array}$ & 140 & $12 \cdot 5$ & $I \cdot 2 *$ \\
\hline On admission $\dagger$ & 45 & $6 \cdot 27$ & $0 * 40^{* *}$ \\
\hline On discharge & 18 & $9 \cdot 70$ & 0.52 \\
\hline
\end{tabular}

Values significantly different from discharge values: ${ }^{*} P<0.05$; *** $P<0.001$.

+ Three high values from atypical children have been omitted, for reasons see p. 405 . 

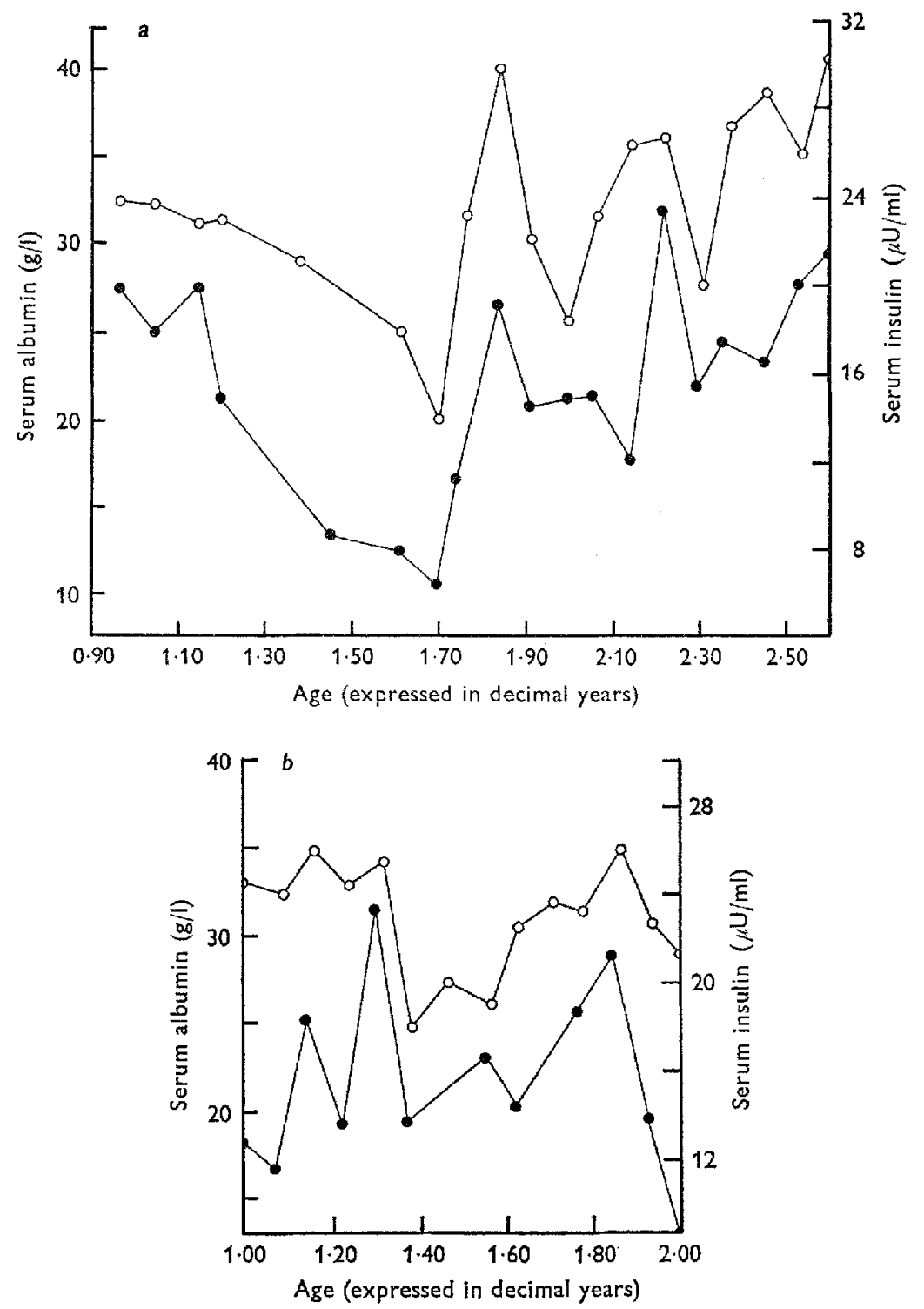

Fig. $5 a, b$. Relative changes in serum albumin $(O)$ and fasting insulin concentrations in two clinic children followed longitudinally.

However, in agreement with Hadden ( 1967 ), not all the admission values were low; three of the forty-eight were, in fact, relatively high, $25 \cdot 7,23 \cdot \mathrm{I}$ and $34 \cdot 5 \mu \mathrm{U} / \mathrm{ml}$. Although these children were definite cases of kwashiorkor, it was apparent that, apart from their oedema, they were not otherwise too severely affected by malnutrition. For example, all had good appetites on admission instead of the more usual anorexia; they showed less body wasting than most of the other children, their weights for length based on the Boston Standards (Stuart \& Stevenson, I954) being 84,87 and $88 \%$ respectively instead of the average value of $78.0 \%$ for the rest of the children. 

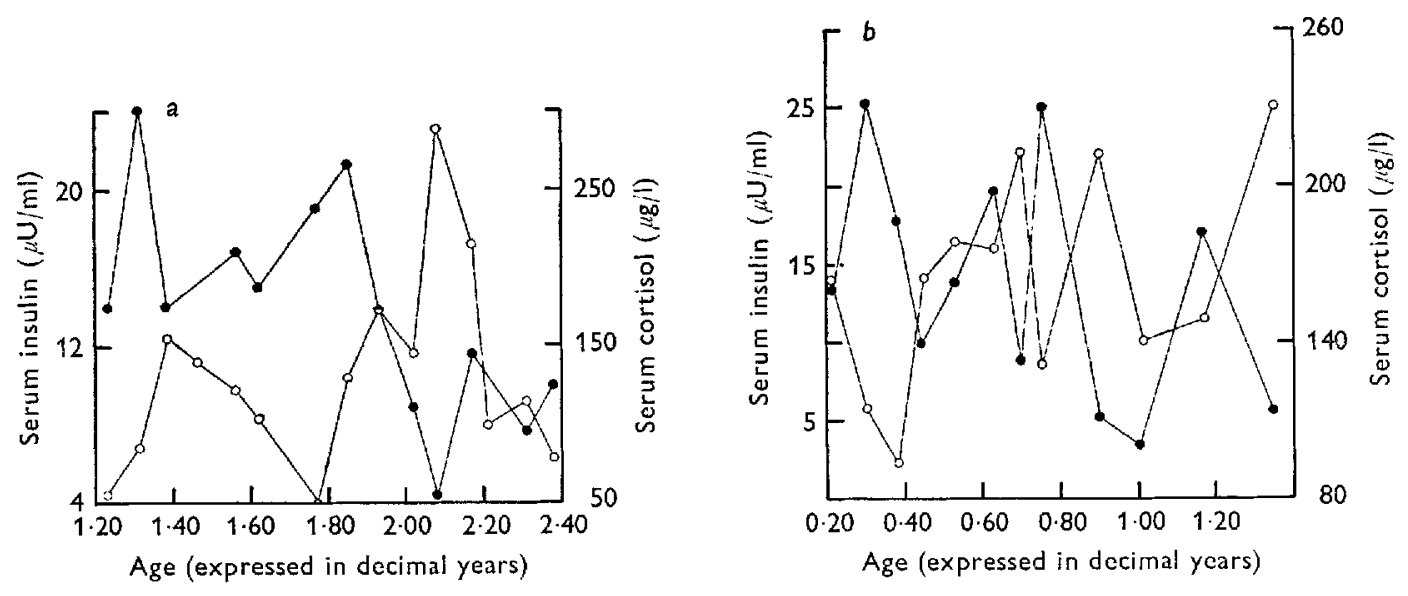

Fig. $6 a, b$. Relative changes in fasting serum cortisol (C) and insulin concentrations in two clinic children studied longitudinally.

Further evidence that a very low serum insulin concentration only occurs in the more severely malnourished child was provided by the results that are shown in Fig. I. On the basis of the values for successfully rehabilitated children, mean serum insulin concentrations were in fact significantly higher than normal $(P>0.05)$ until serum albumin concentration had fallen below $30 \mathrm{~g} / \mathrm{l}$. Insulin concentrations did then start to decrease, but only after albumin had reached the range $\mathrm{I} 8 \cdot \mathrm{I}-22.0 \mathrm{~g} / 1$ were they significantly lower than the ward discharge values.

The close time-relationship between changes in the concentrations of serum insulin and albumin is further demonstrated in the two examples shown in Fig. $5 a, b$ for individual children from the longitudinal study. In each case, when there was a serious hypoalbuminaemic episode, insulin also showed a marked fall in concentration. However, when the children had albumin concentrations which were not so low, above $30 \mathrm{~g} / \mathrm{l}$, insulin concentrations were often quite high, $16-22 \mu \mathrm{L} / \mathrm{ml}$.

From Fig. $I$ it is clear that serum insulin concentration started to fall at the same stage of malnutrition as cortisol concentration began to rise. Fig. $6 a, b$ are further examples of this reciprocal relationship taken from another two individual children attending the clinic.

Since falling albumin concentrations (Frood $e t$ al. I97 I) and rising cortisol concentrations were both associated with episodes of infection, it followed that the falling insulin concentrations also exhibited the same relationship.

\section{GII}

The relationship between GII and albumin concentrations during progressive protein-energy malnutrition of the type that leads to kwashiorkor is also shown in Fig. I. Although there were similarities between the patterns of change in GH and those for cortisol in that both rose with increasing hypoalbuminaemia, there was one important difference. Mean cortisol concentrations showed a substantial rise as soon as albumin concentration fell below $30 \mathrm{~g} / \mathrm{l}$ whereas mean $\mathrm{GH}$ concentrations only 
Vol. 29

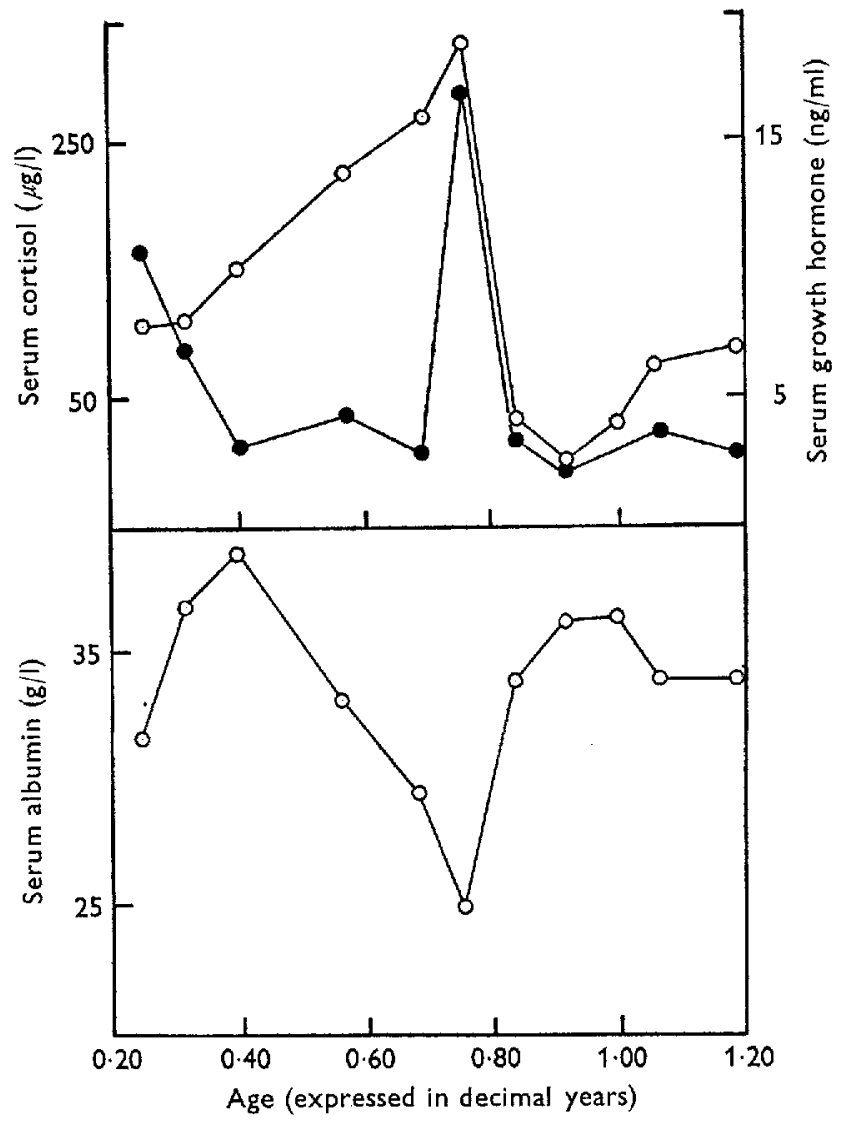

Fig. 7. The different time pattern of response of fasting serum cortisol (O) and growth hormone (e) concentrations during a period of hypoalbuminaemia in a clinic child studied longitudinally. The corresponding changes in albumin concentration are also given.
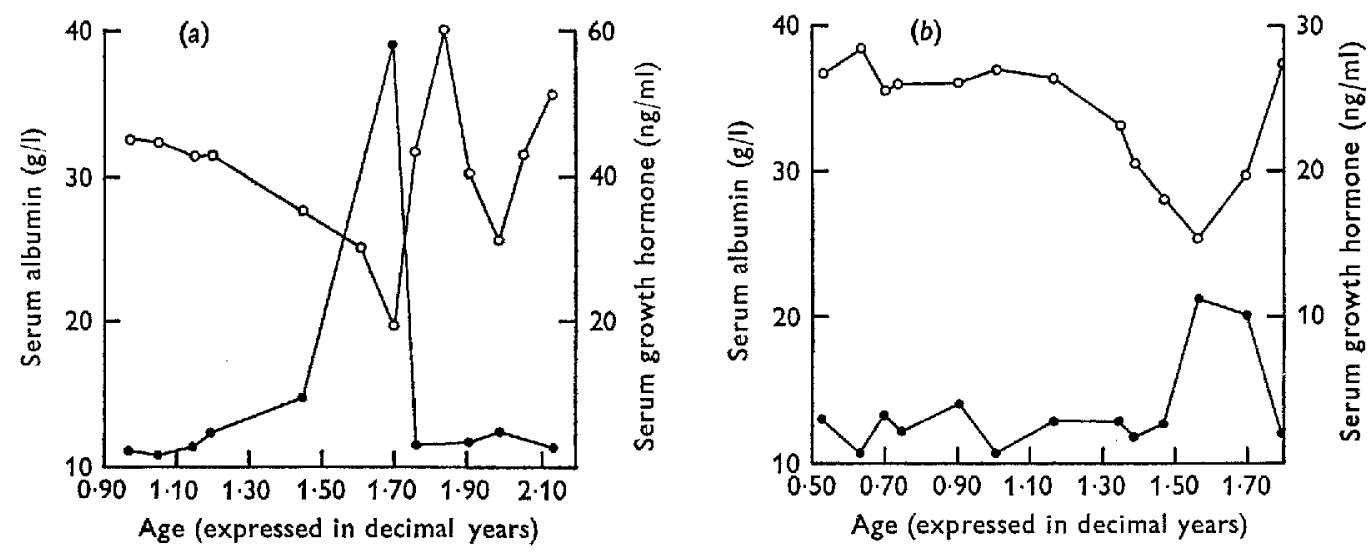

Fig. $8 a, b$. Relative changes in serum albumin $(O)$ and fasting serum growth hormone concentrations ( $)$ in two village children followed longitudinally. 
Table 2. Fasting serum growth hormone concentrations in different types of malnourished children

\begin{tabular}{|c|c|c|c|c|}
\hline & \multirow{2}{*}{$\begin{array}{c}\text { Weight for aget } \\
(\%)\end{array}$} & \multirow[b]{2}{*}{ No. } & \multicolumn{2}{|c|}{$\begin{array}{l}\text { Growth hormone } \\
\quad(\mathrm{ng} / \mathrm{ml})\end{array}$} \\
\hline & & & Mean & $\mathrm{SE}$ \\
\hline Kwashiorkor & $\begin{array}{c}80-100 \\
60-80 \\
<60\end{array}$ & $\begin{array}{r}9 \\
33 \\
22\end{array}$ & $\begin{array}{l}110 \\
10.7 \\
15.3\end{array}$ & $\begin{array}{l}5 \cdot 2^{* * * *} \\
1 \cdot 5^{* * * *} \\
3 \cdot 0^{* * * *}\end{array}$ \\
\hline Marasmus & $<60$ & 3 & $5 \cdot 0$ & $\mathrm{r} \cdot 6$ \\
\hline Clinic children & - & 86 & 3.9 & 0.4 \\
\hline Rehabilitated children & - & 5 & $2 \cdot 7$ & 0.8 \\
\hline
\end{tabular}

Values significantly different from those in the clinic children, *** $P<0$-0or.

$\dagger$ Calculated on the basis of the Boston Standards (Stuart \& Stevenson, 1954) after loss of oedema.

rose significantly after the kwashiorkor range of albumin concentrations had been reached.

The fact that the response of GH to malnutrition was late rather than early is further emphasized by the results from the individual children given in Figs. 7 and $8 a, b$. Fig. 7 shows a delayed rise in $\mathrm{GH}$ concentration in comparison with changes in serum cortisol and albumin concentrations. The hypoalbuminaemic episode had been associated with successive attacks of pneumonia, measles, malaria, and bronchitis, and the steady rise in serum cortisol concentration must have resulted, at least in part, from the stress response to these infections. However, the infections had no effect on GH concentration, which only started to rise after serum albumin had fallen as low as $25 \mathrm{~g} / 1$ and when strictly controlled dietary therapy had to be introduced. In the case shown in Fig. $8 a$ there was progressively developing hypoalbuminaemia for almost a year in spite of intensive attempts at the out-patient clinic to correct this trend. Again GH only responded dramatically when the albumin concentrations had reached a particularly low level. At this time the child had to be admitted to the ward. There was a second episode of hypoalbuminaemia some time after discharge, but on this occasion albumin concentration only reached $26 \mathrm{~g} / 1$ and there was little $\mathrm{GH}$ response. The child in Fig. $8 b$ also showed a rise in GH concentration but only after albumin concentrations had dropped to their lowest value, $25 \mathrm{~g} / 1$.

Table 2 shows the fasting serum GH concentrations in untreated cases of severe malnutrition classified according to weight deficits after the loss of oedema, as described for cortisol. Average values among the clinic children $(3.9 \mathrm{ng} / \mathrm{ml})$ and for a small group of nutritionally rehabilitated cases $(2 \cdot 7 \mathrm{ng} / \mathrm{ml})$ are also given. In marked contrast to cortisol, there was no statistically significant relationship between serum $\mathrm{GH}$ concentrations and the degree of body wasting; in fact, in the marasmic cases, who were the most underweight, the concentrations were the same as those in the clinic children. Another way in which GH differed from cortisol was that there was no relationship between the raised concentrations and the severity of intercurrent infection. In sixteen of the children GH concentrations were also quite unrelated to blood glucose concentration. 


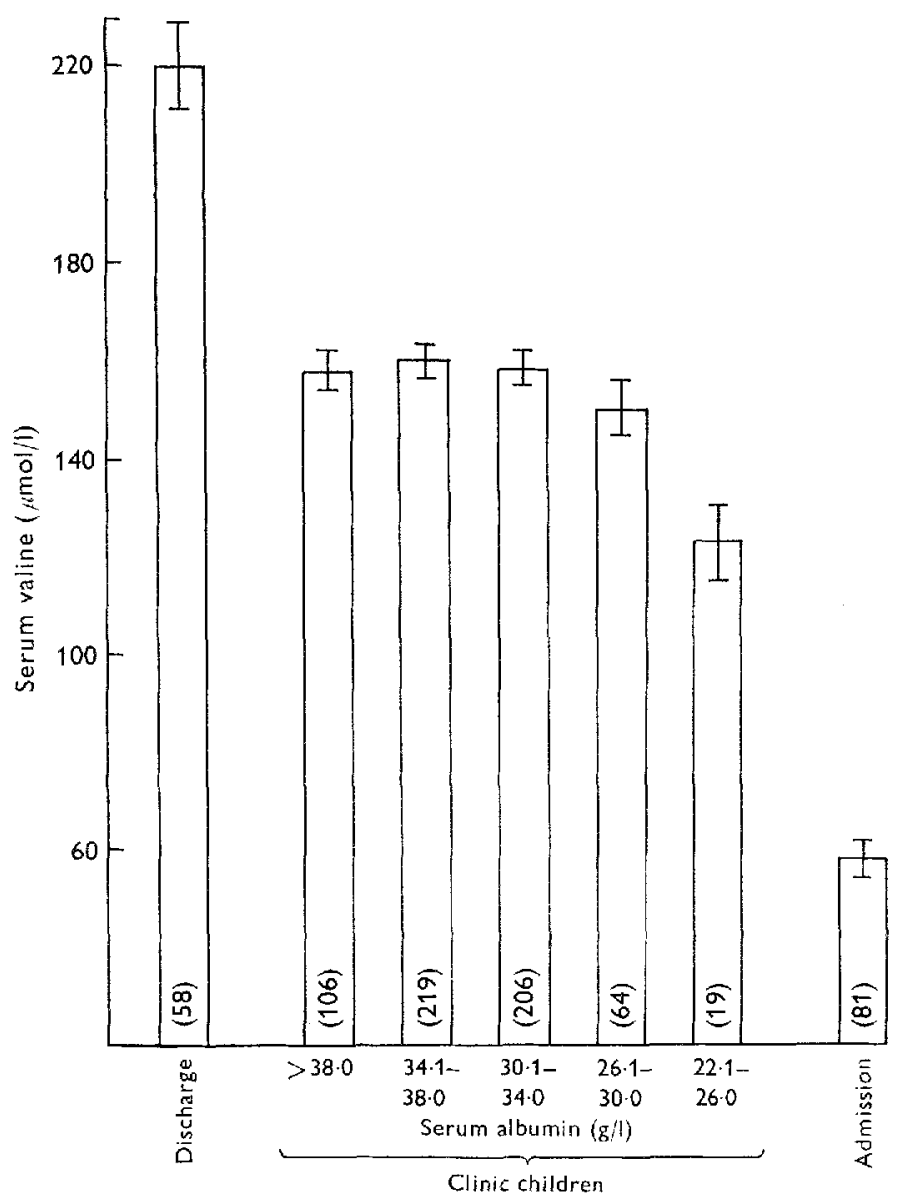

Fig. 9. Relationship between serum valine and albumin concentrations in clinic children grouped according to serum albumin concentration, in cases of frank kwashiorkor on admission and in nutritionally rehabilitated children at discharge. Values are means with their standard errors; numbers in parentheses indicate the number of samples. Mean serum valine concentration in the $22 \cdot \mathrm{I}-26.0 \mathrm{~g} / \mathrm{l}$ albumin range is significantly different from the $26 \cdot \mathrm{I} \rightarrow$ $30.0 \mathrm{~g} / \mathrm{l}$ group, $P<0.05$.

The only measurement that $\mathrm{GH}$ did correlate with was serum albumin concentration; linear regression analysis revealed a highly significant relationship among the kwashiorkor cases $(r=0.53, P<0.001)$.

\section{Serum amino acids}

Valine. In Fig. 9 valine concentrations in the clinic children have been ranked according to serum albumin concentration and the results are compared with corresponding values in children with severe kwashiorkor, all of whom had albumin concentrations below $25 \mathrm{~g} / \mathrm{l}$. Values are also given for successfully rehabilitated children. During the stages when serum albumin values first started to fall, serum valine concentrations remained constant but at significantly lower values than those found in rehabilitated children and those reported for nutritionally normal children by Reid 


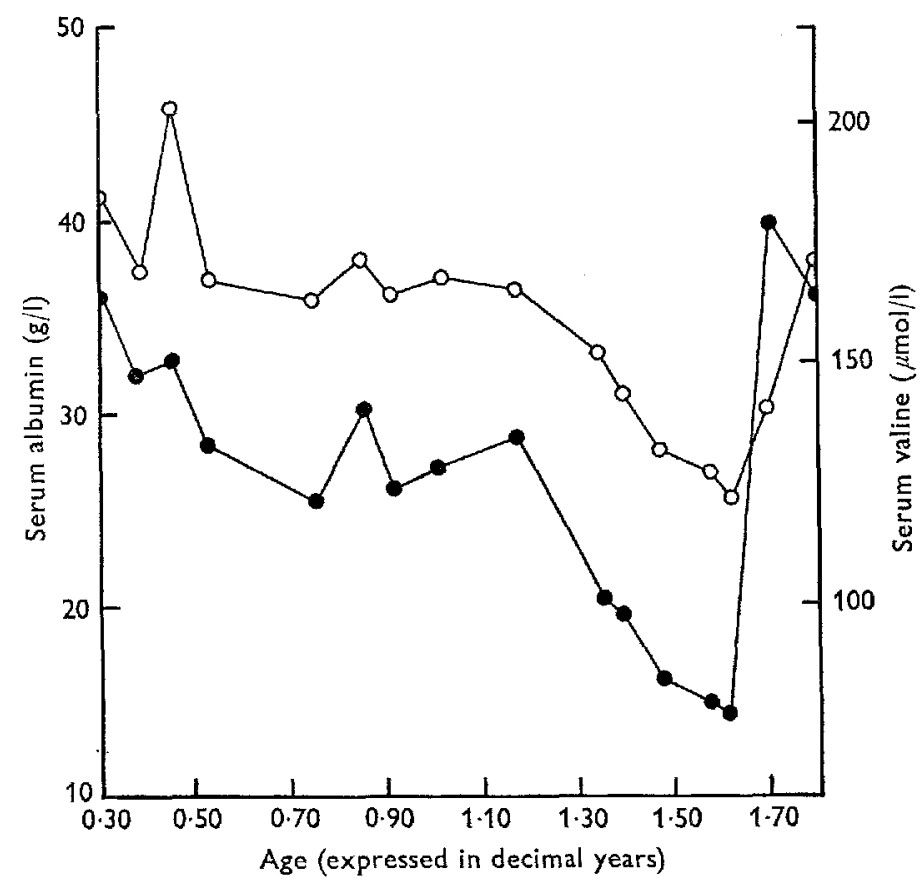

Fig. 10. Relationship between serum albumin $(O)$ and valine (O) concentrations in a clinic child studied longitudinally. Dietary therapy was introduced at $I \cdot 65$ years.

(I966), 280 $\pm 20 \mu \mathrm{mol} / 1$, Van Stekelenburg \& Desplanque (I966), 194 $\pm 5^{8} \mu \mathrm{mol} / \mathrm{l}$, and Grimble \& Whitehead ( $1970 a$ ), $265 \pm 34 \mu \mathrm{mol} / 1$.

Valine concentrations began to fall again and to much lower levels after albumin concentration had dropped below $26 \mathrm{~g} / 1$; very low values were found in cases of severe kwashiorkor.

The same features are well illustrated in the example for an individual child shown in Fig. Io. The reductions in serum valine and albumin concentrations were closely related; both returned rapidly towards normal once controlled dietary therapy had been introduced in the ward.

Alanine. Fasting serum alanine concentrations have been grouped in the same way (Fig. I I). Previously reported values for mean fasting serum alanine concentration in normal children have ranged from 280-402 $\mu \mathrm{mol} / 1$ (Reid, I966; Van Stekelenburg \& Desplanque, I966; Grimble \& Whitehead, I970a). In nutritionally rehabilitated children the mean alanine concentration was $375 \mu \mathrm{mol} / 1$ but during the early stages of hypoalbuminaemia, alanine concentrations were maintained at a level significantly higher than this, $440 \mu \mathrm{mol} / \mathrm{l}$. It was not until serum albumin concentrations dropped below $26 \mathrm{~g} / 1$ that characteristically low alanine concentrations started to develop.

\section{Amino acid patterns and hormonal balance}

Insulin. Mean concentrations of serum valine and alanine grouped according to serum insulin concentrations are shown in Fig. I2. Most serum insulin concentrations 


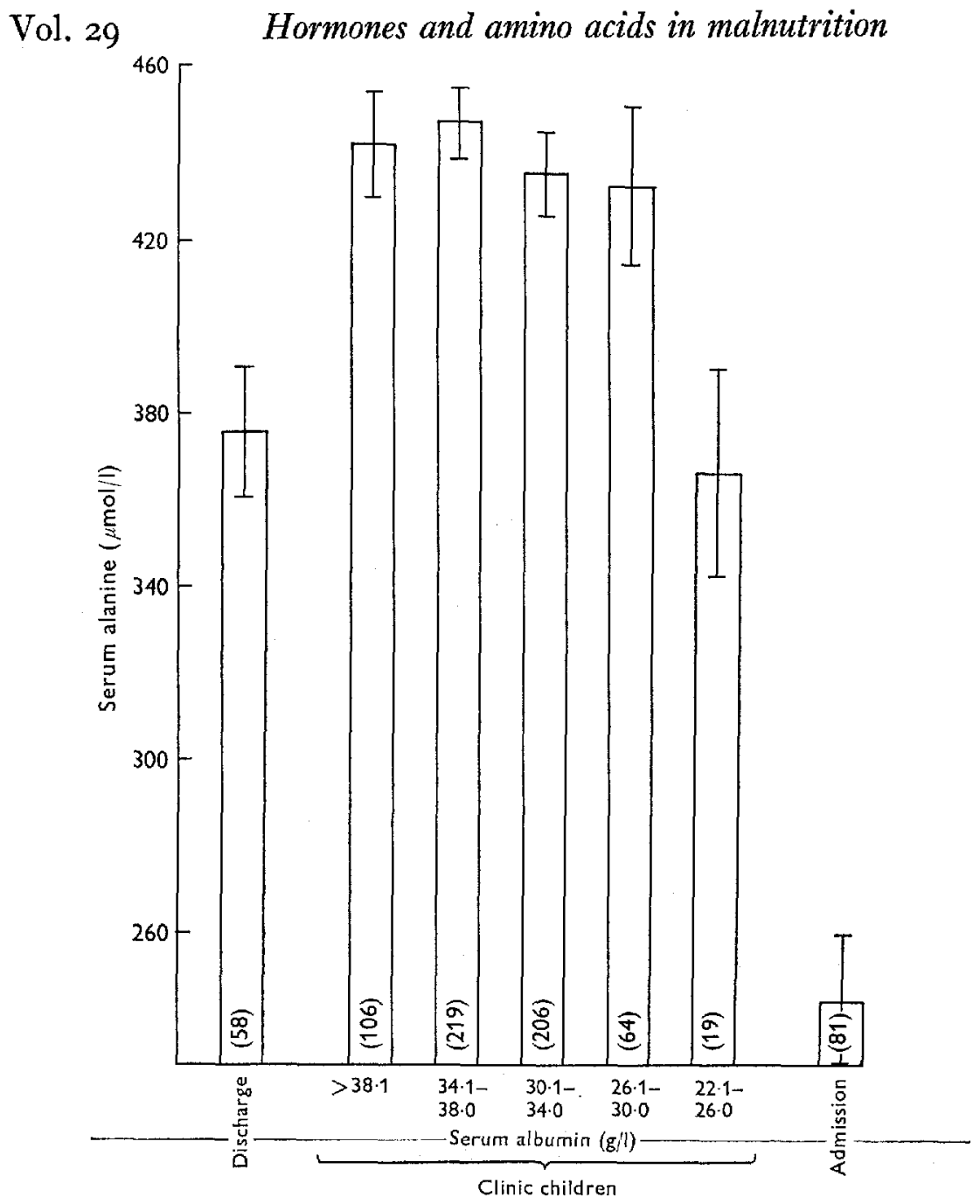

Fig. I I. Relationship between serum alanine and albumin concentrations in clinic children, grouped according to serum albumin concentration, in cases of frank kwashiorkor on admission, and in nutritionally rehabilitated children at discharge. Values are means with their standard errors; numbers in parentheses indicate the number of samples. Mean serum alanine concentrations of the clinic children with albumin values in the $26-38 \mathrm{~g} / \mathrm{l}$ range are significantly higher than those of the rehabilitated children, $P<0.00 \mathrm{r}$; admission values lower than discharge values, $P<0.00$.

in nutritionally rehabilitated children range between $8-12 \mu \mathrm{U} / \mathrm{ml}$. When insulin values were of this order in the clinic children the corresponding serum alanine concentrations were virtually the same, $399 \mu \mathrm{mol} / 1$ at the clinic and $375 \mu \mathrm{mol} / 1$ in the treated children. However, when insulin concentrations were above $12 \mu \mathrm{U} / \mathrm{ml}$ mean alanine concentrations were significantly higher than this, $456 \mu \mathrm{mol} / 1$. Below an insulin value of $8 \mu \mathrm{U} / \mathrm{ml}$ much lower alanine concentrations were obtained, $3^{\mathrm{I}} 3 \mu \mathrm{mol} / \mathrm{l}$. This relationship between fasting insulin and alanine concentrations is substantiated in Fig. I3 which depicts, as an example, the changes for a typical child followed longitudinally. 


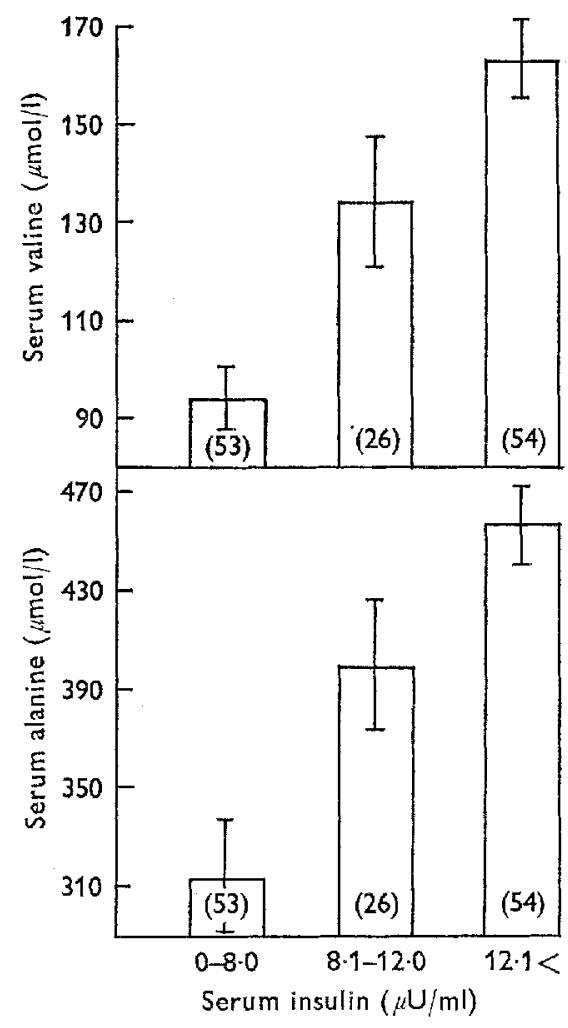

Fig. 12

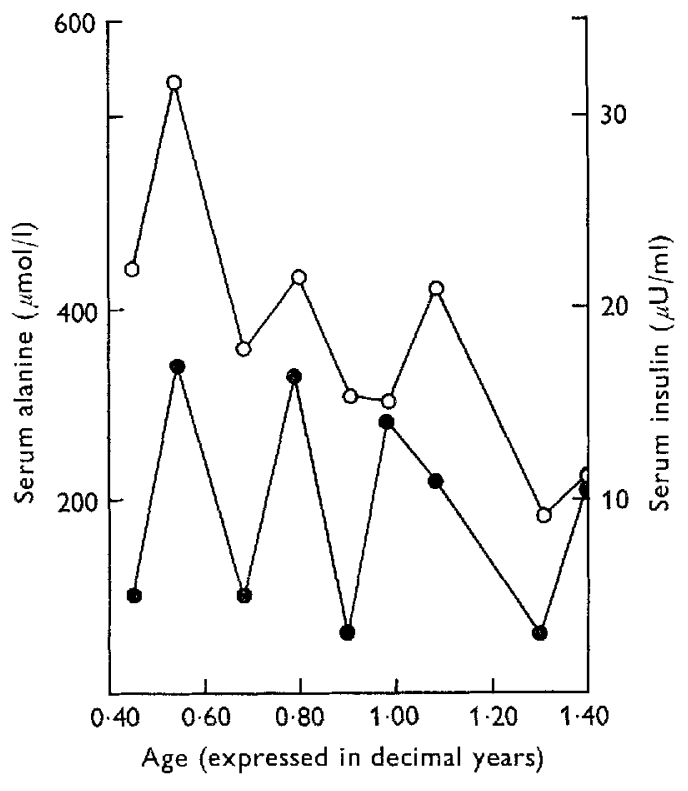

Fig. 13

Fig. 12. Relationship of serum valine and alanine concentrations to fasting serum insulin concentration. Values are means with their standard crrors; figures in parentheses indicate the number of samples. Differences in the concentrations of amino acids from those in the normal (8-12 $\mu \mathrm{U} / \mathrm{ml})$ insulin group are : for valine, below $8 \mu \mathrm{U} / \mathrm{ml}, P<0$ or, above $12 \mu \mathrm{U} / \mathrm{ml}$, $P=0.05$; and for alanine, below $8 \mu \mathrm{U} / \mathrm{ml}, P<0.05$, above $12 \mu \mathrm{U} / \mathrm{ml}, P=0.05$.

Fig. 13. Relative changes in serum alanine $(O)$ and insulin $(\bullet)$ concentrations in a clinic child studied longitudinally.

Serum valine concentration followed the same pattern as alanine but, as will be shown, the very low values found with low insulin concentrations were probably due to the intervention of additional hormonal changes. Even so, the mean serum valine concentration $(163 \mu \mathrm{mol} / \mathrm{l})$ in the group with the highest insulin concentration was still lower than the values for nutritionally rehabilitated children $(220 \mu \mathrm{mol} / 1)$ and normal children (194-280 $\mu \mathrm{mol} / \mathrm{l})$.

Cortisol. The relationships between the serum amino acids and changes in cortisol concentration are illustrated in Figs. 14 and 15 . The effects of cortisol and insulin are antagonistic in respect to both carbohydrate and amino acid metabolism and thus the opposite relationship from that obtained for insulin would be expected. Fasting serum cortisol concentrations in nutritionally rehabilitated children range between 80I $20 \mu \mathrm{g} / \mathrm{l}$. When cortisol concentrations among the clinic and ward children were above $120 \mu \mathrm{g} / \mathrm{l}$, serum alanine concentrations were significantly lower than in children 


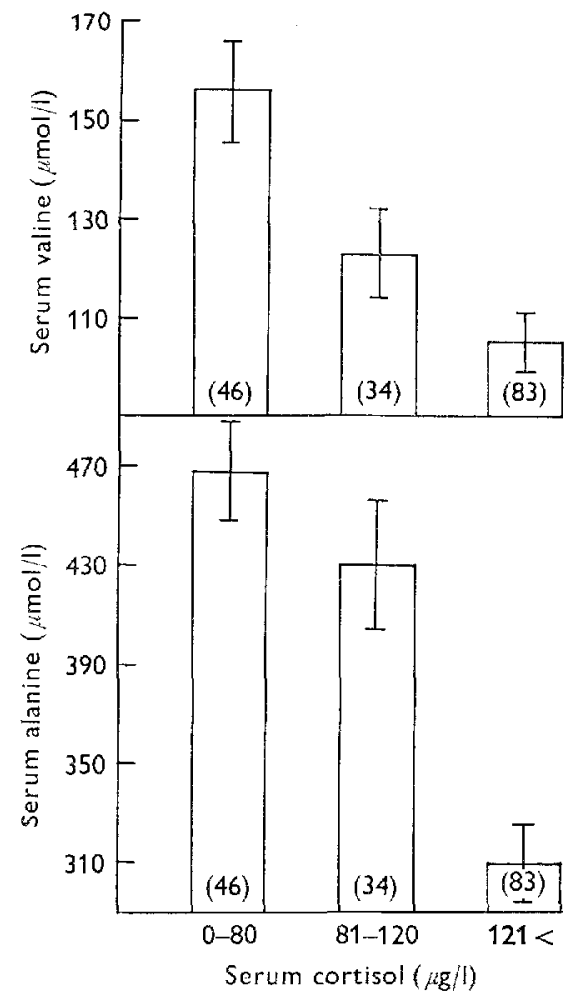

Fig. 14

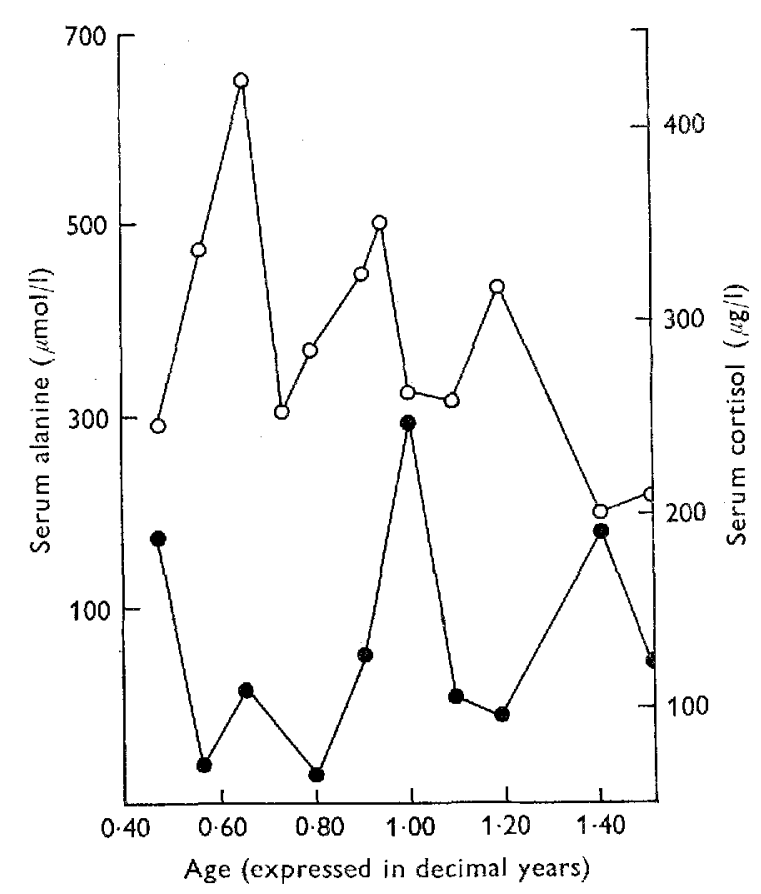

Fig. 15

Fig. 14. Relationship of serum valine and alanine concentrations to serum cortisol concentration. Values arc means with their standard errors: figures in parentheses indicate the number of samples. Differences in the concentrations of amino acids from those in the normal $(80-$ ı $20 \mu \mathrm{g} / 1)$ cortisol group are: for valine, below $80 \mu \mathrm{g} / \mathrm{l}, P<0.05$, above $\mathrm{I} 20 \mu \mathrm{g} / \mathrm{l}$, not significant; and for alanine, below $80 \mu \mathrm{g} / 1$, not significant, above $12 \mu \mathrm{g} / 1, P<0.00 \mathrm{I}$.

Fig. I 5. Relative changes in serum alanine (O) and cortisol (๑) concentrations in a clinic child studied longitudinally.

with more normal cortisol concentrations. This reciprocal relationship between fasting serum alanine and cortisol concentration is further demonstrated in Fig. I 5 .

Valine concentration again followed the same pattern as serum alanine but this relationship was also probably dependent on the superimposed changes in $\mathrm{GH}$ concentration.

GH. Fig. I6 shows the relationship between increasing serum GH concentrations and mean serum alanine and valine values. Since serum GH concentration was only significantly raised in the ward cases and in the more severely affected clinic children most values fall into the normal $0-4 \mathrm{ng} / \mathrm{ml}$ grading. As might be expected from the known effect of $\mathrm{GH}$, there was a large and significant reduction in the concentrations of both amino acids as $\mathrm{GH}$ concentration increased. 


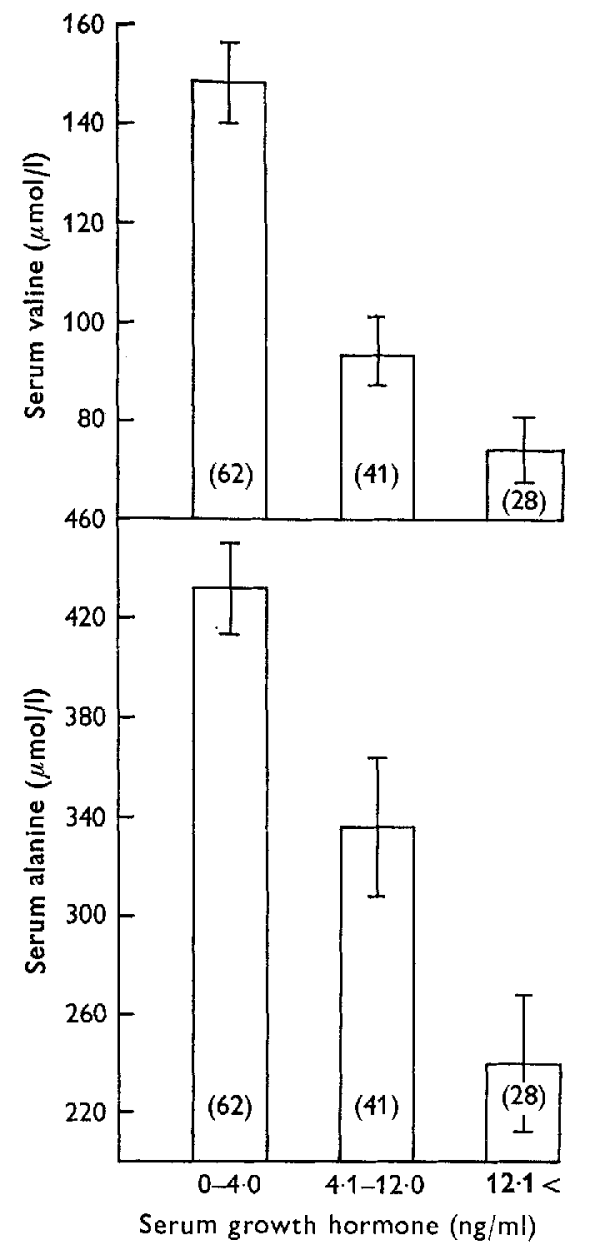

Fig. I6. Relationship of serum valine and alanine concentrations to serum growth hormone concentration. Values are means with their standard errors; figures in parentheses indicate the number of samples. Differences in the concentration of amino acids from those in the normal $(0-4 \mathrm{ng} / \mathrm{ml})$ growth hormone group are: for valine, $4-\mathrm{r} 2 \mathrm{ng} / \mathrm{ml}, P<0.001$, above

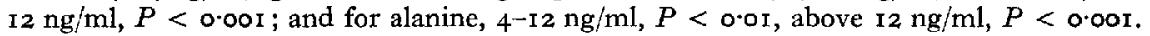

\section{DISCUSSION}

\section{Cortisol}

Adrenal function in severely malnourished children has been the subject of investigation and argument for many years. Contradictory histological findings indicating both atrophy (Trowell, Davies \& Dean, 1954) and hyperfunction (Tejada \& Russfield, 1957) have been published. Subsequent biochemical investigations have also resulted in conflicting impressions. Urinary excretions of 17 -hydroxy- and 17 -keto-steroids in kwashiorkor have been variously reported as normal (Lurie \& Jackson, I962) and low (Baig \& Edozien, I965); Castellanos \& Arroyave (I96I) found low urinary excretions of these steroids in kwashiorkor, but high values in marasmus. However, urinary 
steroid measurements can sometimes be an unreliable guide to adrenal activity (Huseby, Reed \& Smith, 1959; Cope \& Pearson, 1965), and recent investigators have felt that the measurement of plasma cortisol concentration probably provides a more meaningful result. Three groups of workers, Alleyne \& Young (1967) in Jamaica; Abbassy, Mikhail \& Zeitoun (1967a, b) in Egypt and Rao, Srikantia \& Gopalan (1968) in India, have all reported raised plasma cortisol levels in protein-energy malnutrition regardless of the type. Stimulation of the adrenals with adrenocorticotrophic hormone or Synacthen ( $\beta^{1-24}$-corticotrophin) produced the expected increase in plasma cortisol concentrations, showing that the adrenals were still capable of adequate function.

Our results have confirmed that in many children serum cortisol concentrations do become raised in malnutrition but this does not occur immediately; during much of the time while kwashiorkor is evolving, plasma cortisol concentrations are in fact normal or even slightly reduced.

It is important to emphasize, moreover, that cortisol concentrations are not always raised even in severe kwashiorkor. The values on admission covered a wide range, $65-398 \mu \mathrm{g} / \mathrm{l}$. The reason for this scatter is partly clarified by the linear correlation which was found to exist between serum cortisol concentration and expected weight for age. When there was minimum weight deficit, and the children conformed more to the 'classical' type of kwashiorkor, cortisol concentration was essentially normal. High cortisol concentrations were mainly found in the marasmic type of kwashiorkor, in fact in these children the values were the same as in marasmus. Our findings could rationalize to some extent part of the controversy which has surrounded opinions on adrenal activity in malnutrition, for at least in Uganda there is a continuous range of serum cortisol concentration across the protein-energy spectrum, even in severely malnourished children. In this respect, the present results are in accord with the earlier conclusions of Castellanos \& Arroyave (1961) who considered that adrenal activity was generally low in kwashiorkor but high in marasmus. Our results are also not at variance with those of Alleyne \& Young ( 1967 ), whose children averaged $68 \%$ expected weight for height and in whom there was no difference between children with and without oedema (kwashiorkor or marasmus); but no difference would be expected in such underweight children. The results of Abbassy et al. (1967a,b) also show that the highest cortisol values were found in the most underweight children.

\section{Stimuli for the changes in cortisol concentration}

High serum cortisol concentrations were often associated with bouts of severe infection, especially when the child suffered a series of illnesses. The control of cortisol secretion has been discussed by Catt (1970a). Increased cortisol concentrations are commonly seen in stress, including the stress of infection; thus the connexion between high serum cortisol concentrations and the severity of infection in both the rural children and in the cases admitted with kwashiorkor was not surprising. However, Alleyne \& Young (1967), working in Jamaica, did not consider that infection could have been the primary cause of the high cortisol concentrations in their children since none had exhibited overt clinical signs, but they were able to demonstrate a good correlation between cortisol and fasting blood glucose. They concluded, therefore, 
that the high cortisol concentrations were probably a direct metabolic response to hypoglycaemia. Although this was not confirmed in Uganda, it does not necessarily mean that the need to maintain blood glucose was not a factor in producing raised cortisol concentrations. Partial anorexia and an inadequate total energy intake resulting from infection is an important aetiological factor in the development of the final stages of malnutrition in Ugandan children (Frood et al. r97 I). At this time cortisol-induced gluconeogenesis must be of importance but, since this adaptation was apparently effective, perhaps no mathematical correlation should have been expected.

The interpretation of cortisol concentrations in kwashiorkor might be further complicated by a reduced hepatic clearance rate (Alleyne \& Young, I967). This could, however, just be part of the mechanism by which the body maintains raised plasma concentrations; similar processes operate with other metabolites of homoeostatic importance.

\section{Insulin}

Most reports on fasting serum insulin concentrations in protein-energy malnutrition have described values which are lower than normal (Baig \& Edozien, I965; James \& Coore, I970; Milner, 1971). The exception is the work of Hadden (1967) who, while agreeing that fasting insulin concentrations were low in marasmus, claimed that valucs in Ugandan children with kwashiorkor were normal and could even be high. In certain respects these findings were difficult to understand since the onset of kwashiorkor is normally associated with a reduced total food intake and often frank anorexia. This by itself would be expected to result in a lowered insulin activity even if there were no additional pancreatic insufficiency resulting from malnutrition (Milner, I970). Our results have revealed that fasting serum insulin concentrations pass through two distinct phases during the aetiology of kwashiorkor: an initial phase, when insulin concentrations are relatively high, followed by a second phase, culminating in clinical kwashiorkor, in which insulin becomes reduced in concentration.

These time-relationships offer an explanation of the different results obtained from Uganda by Hadden (1967). Perhaps the group of children in which he found high fasting values were like our three children with similarly raised insulin concentrations. These cases, apart from their oedema, had not been so severely affected by malnutrition; it seemed likely, therefore, that the high insulin concentrations normally found only during the early stages of malnutrition had still persisted.

\section{Stimuli for the changes in insulin concentration}

The relatively high fasting insulin concentrations which were found during the initial stages of malnutrition were probably due to the high carbohydrate content of the local diet; approximately $88 \%$ of the energy intake being derived from this source. Blazquez \& Lopez-Quijada ( 1969 ) have demonstrated that fasting insulin concentrations became set at a higher level in rats fed on foods with a high carbohydrate content compared with others living on isoenergetic but better-balanced diets. Even though on average the children were receiving only about $70 \%$ of the internationally recommended amount of energy (Rutishauser $\&$ Whitehead, I972), carbohydrate intake was still in excess of that in normal European children. 
The subsequent falls in insulin concentration were usually associated with successive bouts of infection which were accompanied by faltering of growth and sometimes by loss of weight and more marked hypoalbuminaemia. During periods of infection, partial anorexia was a main feature (I. H. E. Rutishauser, in preparation), and the consequent reduction in carbohydrate intake which occurred would be expected to produce a fall in insulin secretion. The very low concentrations found in kwashiorkor could be due, in part, to the same cause since gross mental apathy and complete anorexia are often present. In fact, Cahill, Herrera, Morgan, Soeldner, Steinke, Levy, Reichard \& Kipnis (I966) have suggested that a decreased insulin secretion is the primary regulator for the supply of energy metabolites from endogenous sources when intake becomes inadequate.

Apart from this explanation, which could be considered as a quite normal homoeostatic response, it has been suggested that an impaired function of the islets of Langerhans might also be important. Both an impaired glucose tolerance and a reduced insulin response to stimulation by intravenous glucose and glucagon have been demonstrated in children with kwashiorkor (Hadden, 1967; Milner, 1970). However, histological evidence does not indicate atrophy of the islets of Langerhans; indeed Tejada \& Russfield (I957) have stated that these cells have a normal or even hyperplastic appearance. Moreover an impaired glucose tolerance can be produced after even a short period of starvation in healthy adults (Vance, Buchanan \& Williams, I 968) and, therefore, this by itself does not constitute proof of impaired function. Grimble \& Whitehead ( 197 I $b$ ) have also demonstrated that a glucose load still stimulates the passage of amino acids out of the plasma even in severe kwashiorkor. Since this metabolic process is mediated by insulin, secretion by the islets of Langerhans cannot be too severely impaired. No definite explanation for the eventually low insulin concentrations can thus be given; to what extent they result from normal homoeostatic processes of adaptation, a reduced rate of insulin synthesis or from actual pathological changes needs further investigation.

\section{$G H$}

It is generally agreed that in severe kwashiorkor serum GH concentrations are raised (Pimstone, Wittmann, Hansen \& Murray, 1966; Hadden, I967; Pimstone, Barbezat, Hansen \& Murray, I968; Milner, I970; Beas, Contreras, Maccioni \& Arenas, 1971). The situation in marasmus is rather more confused; Pimstone et al. ( 1968 ) reported that $\mathrm{GH}$ concentrations were raised as in kwashiorkor but Beas et al. (197 I) claimed that GH was normal or even slightly low in nutritional dwarfism. In anorexia nervosa, which in an extreme form is in some ways similar to marasmus, GH concentrations have been variously reported as high (Marks, Howorth \& Greenwood, r965) and low (Hamwi \& Tzagournis, 1970).

The present results confirm that in kwashiorkor, GH concentrations do become raised, but the timing of the response was different from that of both insulin and cortisol. Changes in GH concentrations were virtually confined to the final clinical stage of the pathogenesis of kwashiorkor; this is in contradiction to the conclusion of Waterlow \& Alleyne ( $197 \mathrm{I}$ ), from a review of the limited information available to them in the literature, that GH responded to protein deficiency of recent onset. The high 
GH values, which were found in the most hypoalbuminaemic cases, fell into the range quoted for acromegaly (Catt, $1970 b$ ).

The close correlation which existed between GH concentration and hypoalbuminaemia had previously been observed in severely malnourished children by Pimstone et al. (1968). Beas et al. (1971) subsequently showed that GH concentrations were raised in kwashiorkor cases with advanced hypoalbuminaemia but that this was not the situation in underweight nutritionally dwarfed children who did not exhibit markcd hypoalbuminaemia. In these cases quite normal or even low values were obtained. In agreement, the present results also demonstrated that, unlike cortisol, rises in $\mathrm{GH}$ concentration were unrelated to weight deficit. In the marasmic children, all of whom were grossly wasted but had serum albumin values above $20 \mathrm{~g} / \mathrm{l}, \mathrm{GH}$ concentrations were not affected. Beas et al. (1971) explained their results by suggesting that in marasmus as opposed to kwashiorkor, there was reduced pituitary function. Dickerman, Negro-Vilar \& Meites (1969) also found low plasma and pituitary GH concentrations in starved rats.

\section{Stimuli for the changes in $G H$ concentration}

It is not easy to understand why the GH concentrations only become raised in the final stage of the development of kwashiorkor although one well-known stimulus for GH release from the pituitary is hypoglycaemia. A tendency to this condition in kwashiorkor has been reported by many workers and has been reviewed by McCance (1971). Kwashiorkor is usually associated with anorexia; the maintenance of blood glucose concentrations at this time must be of homoeostatic importance to the child. Unfortunately, too few glucose estimations were available for the children in this study for a conclusive comment to be made, but both Pimstone et al. (1968) and Milner (1971) have failed to show any significant correlation between fasting serum GH and blood glucose concentrations. Moreover Pimstone, Barbezat, Hansen \& Murray (1967) and Pimstone et al. (1968) demonstrated that neither glucose infusion nor the giving of diets of high carbohydrate content had any effect on GH concentrations; they fell only after protein supplementation. It can only be concluded, therefore, that hypoglycaemia was not the main reason for the rise in the serum GH concentrations during the terminal stage.

Pimstone et al. ( 1966 ) originally postulated that it could be the low serum amino acid content which stimulated GH release, but this seems unlikely as another important effect of $\mathrm{GH}$ is to promote the uptake of amino acids into the tissues and this would decrease still further, rather than correct, the serum amino acid concentrations; on the contrary, in normal individuals it is high serum amino acid concentrations which stimulate GH release rather than the reverse (Raiti \& Blizzard, 1970). However, Milner (1970) has provided some evidence which might mean that the response of GH to amino acid loading is different in malnourished children.

Pimstone $e t$ al. (1968) subsequently suggested that GH release was directly related to chronic protein depletion, as measured by plasma albumin concentration. In their more recently published studies, Kernoff, Pimstone, Solomon \& Brock (I97 I) have provided some additional evidence which might indicate that $\mathrm{GH}$ action on albumin 
synthesis and catabolism is related to the size of the intravascular albumin pool. However, it is difficult to see how reduction in serum albumin concentration could have directly stimulated GH secretion in our children since albumin had been falling for many months before the hormone was affected. It would be a poor protective mechanism which allowed albumin to fall to pathologically low concentrations before responding. Clearly there is need for more detailed investigation into the stimulus for the raised concentrations of $\mathrm{GH}$ associated with gross hypoalbuminaemia.

\section{Hormonal balance}

It was obvious that there were two distinct stages during progressive hypoalbuminaemia in which the hormonal balance was quite different. In the first, fasting serum cortisol and GH concentrations were essentially normal but insulin concentration was raised. In the second stage insulin concentration became lower than normal but cortisol and GH concentrations increased in most cases. Since these hormones are believed to affect amino acid transfer into and out of the plasma, it was interesting to note that corresponding patterns of change occurred in the amino acids measured in the serum.

\section{Serum amino acids}

Investigations in experimentally protein-malnourished pigs (Grimble \& Whitehead, $1970 \mathrm{~b}$ ) showed that there were basically three different phases in the development of the changes in the fasting serum amino acid pattern. In phase A, growth, serum protein and amino acid patterns were little affected in spite of a reduced protein intake, probably because the animal was able to adapt adequately. Phase A progressed quickly into phase $\mathrm{B}$ once the protein concentration of the diet was further reduced but while appetite was maintained there was no loss of weight: fasting serum valine concentrations, however, began to fall but alanine concentrations became raised above normal levels. Phase $\mathrm{C}$ was dominated by anorexia and a loss of weight. Valine concentrations continued to fall, eventually reaching very low values; serum alanine was no longer present in increased concentrations; in fact, ultimately, values became lower than normal.

The results now presented from children have confirmed those previously obtained using experimentally malnourished pigs in that during progressive hypoalbuminaemia the serum amino acid pattern passed through two distinct phases. In the first, equivalent to that of phase $B$ in the pig, valine concentrations did fall to moderately low concentrations but alanine concentrations were maintained at values higher than normal. At a later stage both alanine and valine concentrations dropped to levels which were definitely subnormal, as in the pig during phase $\mathrm{C}$. The valine concentrations paralleled the changes in albumin quite closely and very low concentrations developed only when the children were severely affected by malnutrition.

\section{Hormonal interaction and serum amino acid patterns}

Phase $B$. The fact that moderately low valine concentrations in the region of I $60 \mu \mathrm{mol} / 1 \mathrm{can}$ develop quickly once protein but not energy intake is decreased has been shown by many workers (Arroyave, 1962; Swendseid, Tuttle, Figueroa, Mulcare, 
Clark \& Massey, 1966; Pereira, Begum, Sundararaj \& Dumm, i968; Young \& Scrimshaw, 1968; Adibi \& Drash, 1970). A moderate rise in fasting serum alanine concentration at the same time is also well documented (Arroyave, I962; Holt, Snyderman, Norton, Roitman \& Finch, 1963; Young \& Scrimshaw, 1968; Adibi \& Drash, 1970). During this phase of malnutrition in the children the corresponding serum insulin concentrations were relatively high but serum cortisol and GH remained normal. Thus the early concentration changes in serum valine were as one might have expected since a high carbohydrate intake and the increased insulin secretion which results have already been shown to stimulate the movement of essential amino acids out of the serum (Schmidt \& Eastland, 1935; Munro, 1956; Manchester \& Young, I96r; Swendseid, Tuttle, Drenick, Joven \& Massey, 1967; Grimble \& Whitehead, I97 $b$ ) into muscle (Harris \& Harris, I947; Munro, 1956; Munro, Black \& Thomson, 1959). Similarly, the raised alanine concentrations might also have been expected. The rate of insulin secretion is thought to be an important regulator of hepatic gluconeogenesis for which alanine is the main substrate (Cahill et al. 1966; Felig, Owen, Wahren \& Cahill, I969). These investigators suggested that low serum insulin concentrations stimulate gluconeogenesis but this mechanism is inhibited by high insulin concentrations. Increased serum alanine concentrations would therefore be expected on a high carbohydrate intake when there must be little need for gluconeogenesis. Consequently the changes in phase $\mathrm{B}$ both in valine and alanine must probably be regarded as the physiological response to an imbalanced diet.

Phase $C$. This explanation would not hold for the subsequent and more dramatic falls in fasting serum valine concentrations, to well below $100 \mu \mathrm{mol} / 1$ in phase C. These were definitely associated with the onset of pathological changes and were probably the product of many interrelated abnormalities developing at this time. The antianabolic effects of the by now high concentrations of serum cortisol coupled with low insulin concentrations should have replenished serum amino acid concentrations by reducing amino acid utilization for protein synthesis in the muscle (Munro, I964; Catt, I970 a). The fact that this did not occur could at least in part have been due to the overriding effects of the greatly increased GH concentrations. Although the actions of cortisol and $\mathrm{GH}$ are complementary in maintaining blood glucose concentrations, they are antagonistic in their effects on amino acid metabolism. In contrast to cortisol, GH stimulates the passage of amino acids out of the serum into the tissues as part of its anabolic action. This would tend to reduce both valine and alanine concentrations, as well as those of the other free amino acids. A fall in total serum amino acid concentration in kwashiorkor (see Waterlow \& Alleyne, 197I) and in severe protein malnutrition in experimental animals (Grimble \& Whitehead, 19706 ) is well established. Another factor which might further reduce the availability of serum valine in protein malnutrition is the increased activity of the branched-chain amino acid transaminases in the muscle as reported by Mimura, Yamada \& Swendseid (1968). It is of significance that these transaminases are activated by high cortisol concentrations and these coupled with a shunting of valine into muscle by the high GH concentrations might actually increase valine catabolism. This could be the explanation for the very low concentrations of serum valine, the amino acid which seems particularly affected 
in severe kwashiorkor. This interpretation is supported by the recent results of Neale (1971), who showed that in protein-depleted rats the oxidative catabolism of valine and leucine was not reduced and thus these amino acids could not be conserved.

The general lack of appetite and often complete anorexia which accompanies kwashiorkor must increase the need for gluconeogenesis. The relationships which were demonstrated between fasting serum alanine and both serum cortisol and insulin concentrations support the conclusion that the low alanine concentrations which were found in phase $\mathrm{C}$ were probably due mainly to increased gluconeogenic activity.

\section{Conclusion}

From our results it would seem that the final rise in GH concentration might be of profound importance in the final precipitation of the subclinically malnourished child into clinical kwashiorkor. A fall in the concentration of serum amino acids, particularly the branched-chain ones, is known to seriously affect albumin synthesis by the liver (Kirsch, Saunders, Frith, Wicht, Kelman \& Brock, I969). If this is so, then the rise in serum $\mathrm{GH}$ concentration must be regarded as a response of important pathological significance rather than as merely a beneficial physiological adaptation for nitrogen conservation (Waterlow \& Alleyne, 1971). While there is still much to be learnt about $\mathrm{GH}$ release in kwashiorkor, the terminal rise in the plasma concentrations of the hormone must have far-reaching metabolic consequences quite apart from their effect on amino acid metabolism (Catt, 1970b). It might help to separate the different physiological and pathological processes which terminate in either kwashiorkor or marasmus, but this will be discussed elsewhere. We would also like to emphasize that studies into the time-relationships between the development of the different abnormalities associated with kwashiorkor can only suggest biochemical mechanisms. Final proof for cause and effect relationships can only be obtained by direct experimentation.

\section{REFEREN CES}

Abbassy, A. S., Mikhail, M. \& Zeitoun, M. M. (1967a). 7. trop. Paed. r3, 87.

Abbassy, A. S., Mikhail, M. \& Zeitoun, M. M. (1967b). F. trop. Paed, 13, I54.

Adibi, S. A. \& Drash, A. L. (1970). F. Lab. clin. Med. 76, 722.

Alleyne, G. A. O. \& Young, V. H. (1967). Clin. Sci. 33, 189.

Arroyave, G. (1962). Am. F. clin. Nutr. I1, 447 .

Baig, H. A. \& Edozien, J. C. (1965). Lancet ii, 662.

Beas, F., Contreras, I., Maccioni, A. \& Arenas, S. (197 I). Br. F. Nutr. 26, I69.

Blazquez, E. \& Lopez-Quijada, C. (I969). F. Endocr. 44, 107.

Cahill, G. F. Jr, Herrera, M. G., Morgan, A. P., Soeldner, J. S., Steinke, J., Levy, P. L., Rcichard, G. A. \& Kipnis, D. M. (1966). F. clin. Invest. 45, I75 I.

Castellanos, H. \& Arroyave, G. (r961). Am. F. clin. Nutr. 9, I86.

Catt, K. J. (I970a). Lancet i, I275.

Catt, K. J. (1970b). Lancet i, 933 .

Cope, C. L. \& Pearson, J. (1965). F. clin. Path. 18, 82.

Coward, D. G., Sawyer, M. B. \& Whitehead, R. G. (1971). Am. F. clin. Nutr. 24, 940.

Dickerman, E., Negro-Vilar, A. \& Meites, J. (I g69). Endocrinology 84, 8I4.

Ely, R. S., Kelly, V. C. \& Raile, R. B. (1953). F. Paed. 42, 38.

Felig, P., Owen, O. E., Wahren, J. \& Cahill, G. F. Jr (1969). \%. clin. Invest. 48, 584.

Frood, J. D. L., Whitehead, R. G. \& Coward, W. A. (1971). Lancet ii, 1047.

Grimble, R. F. \& Whitehead, R. G. (I970a). In Technicon Quarterly, Vol. 3, no. 3. New York: Technicon Inc.

Grimble, R. F, \& Whitehead, R. G. (1970b). Br. F. Nutr. 24, 557. 
Grimble, R. F. \& Whitehead, R. G. (1971 a). Clinica chim. Acta 31, 355.

Grimble, R. F. \& Whitehead, R. G. (197 I b). Br. F. Nutr. 25, 253.

Hadden, D. R. (1967). Lancet ii, 589 .

Hales, C. N. \& Randle, P. J. (1963). Biochem. F. 88, т37.

Hamwi, G. J. \& Tzagournis, M. (1970). Am. F. clin. Nutr. 23, 3 I I.

Harris, M. M. \& Harris, R. S. (1947). Proc. Soc. exp. Biol. Med. 64, 47r.

Holt, L. E., Snyderman, S. E., Norton, P. M., Roitman, E. \& Finch, J. (1963). Lancet ii, 1343.

Huseby, R. A., Reed, F. C. \& Smith, T. E. (1959). F. appl. Physiol. 14, 3 I.

James, W. P. T. \& Coore, H. G. (1970). Am. F. clin. Nutr. 23, 386.

Kernoff, L. M., Pimstone, B. L., Solomon, J. \& Brock, J. F. (1971). Biachem. F. 124, 529.

Kirsch, R., Saunders, S. J., Frith, L., Wicht, S., Kelman, L. \& Brock, J. F. (1969). Am. F. clin. Nutr. 22, 1559 .

Lurie, A. O. \& Jackson, W. P. U. (1962). Clin. Sci. 22, 259.

McCance, R. A. (I97I). In Recent Advances in Paediatrics, $4^{\text {th }}$ ed., p. 479 [D. Gairdner and D. Hull, editors]. London: Churchill.

Manchester, K. I. \& Young, F. G. (r96r). Vitams Horm. r9, 95.

Marks, V., Howorth, N. \& Greenwood, F. C. (1965). Nature, Lond. 208, 686.

Milner, R. D. G. ( 1970 ). In Hormones and the Environment Memoirs of the Society for Endocrinology, no. 18, p. I9 [G. K. Benson and J. G. Phillips, editors]. London: Cambridge University Press.

Milner, R. D. G. (197I). Paediat. Res. 5, 33.

Mimura, T., Yamada, C. \& Swendseid, M. E. (т968). F. Nutr. 95, 493.

Molinatti, G. M., Massara, F., Strumia, E., Pennisi, F., Scasellati, G. A. \& Vancheri, L. (1969). $\mathscr{f}$. nucl. Biol. Med. I3, $\mathbf{1 .}$

Munro, H. N. (1956). Scott. med. \%. I, 285.

Munro, H. N. (1964). In Mammalian Protein Metabolism, Vol. I, ch. ro [H. N. Munro and J. B. Allison, editors]. New York and London: Academic Press Inc.

Munro, H. N., Black, J. G. \& Thomson, W. S. T. (1959). Br. F. Nutr. 13, 475.

Murphey, B. E. P. (1967). F. clin. Endocr. 27, 973 .

Neale, R. J. (197I). Nature, New Biology 23r, I77.

Pereira, S. M., Begum, A., Sundararaj, R. \& Dumm, M. E. (1968). Am. f. clin. Nutr. 2r, I67.

Pimstone, B. L., Barbezat, G., Hansen, J. D. L. \& Murray, P. (I967). Lancet ii, I333.

Pimstone, B. L., Barbezat, G., Hansen, J. D. L. \& Murray, P. (1968). Am. J. clin. Nutr. 2 r, 482.

Pimstone, B. L., Wittman, W., Hansen, J. D. L. \& Murray, P. (I 966). Lancet ii, 779.

Raiti, S. \& Blizzard, R. M. (1970). Adv. Paed. 17, 99.

Rao, K. S. J., Srikantia, S. G. \& Gopalan, C. (I 968). Archs Dis. Childh. 43, 365.

Reid, R. H. P. (1966). In Techniques in Amino Acid Antalysis, p. 43. Chertsey, England: Technicon.

Rutishauser, I. H. E. \& Whitchead, R. G. (I972). Br. F. Nutr. 28, 145.

Schmidt, E. G. \& Eastland, J. S. (1935). F. Lab. clin. Med. 20, I.

Staff, T. H. E. (1968). E. Afr. med. $\mathcal{F} .45,399$.

Stuart, H. C. \& Stevenson, S. S. (1954). In Textbook of Pediatrics, 8th ed., p. $4^{8}$ [W. E. Nelson, editor]. Philadelphia: Saunders.

Swendseid, M. E., Tuttle, S. G., Drenick, E. J., Joven, C. B. \& Massey, F. J. (1967). Am. F. clin. Nutr. 20, 243.

Swendseid, M. E., Tuttle, S. G., Figueroa, W. S., Mulcare, D., Clark, A. J. \& Massey, F. J. (r966). F. Nutr. 88, 239 .

Tejada, C. \& Russfield, A. B. (1957). Archs Dis. Childh. 32, 343.

Trowell, H. C., Davies, J. N. P. \& Dean, R. F. A. (1954). In Kwashiorkor. London: Arnold.

Vance, J. E., Buchanan, K. O. \& Williams, R. H. (1968). F. Lab. clin. Med. 72, 290.

Van Stekelenburg, G. J. \& Desplanque, J. (1966). In Techniques in Amino Acid Analysis, p. 5 I. Chertsey, England: Technicon.

Waterlow, J. C. \& Alleyne, G. A. O. (1971). Adv. Protein Chem. 25, I I7.

Wellcome Trust Working Party (1970). Lancet ii, 302.

Young, V. R. \& Scrimshaw, N. S. (1968). Br. F. Nutr. 22, 9. 